\title{
Visions About Mobile Technologies in Elementary Education
}

\author{
Harri Ketamo, Jarkko Alajääski and Jari Multisilta \\ Pori School of Technology and Economics, Tampere University of Technology, Po.Box 300, \\ 28101 Pori, Finland \\ harri.ketamo@pori.tut.fi \\ Department of Teacher Education in Rauma, University of Turku, 26100 Rauma, Finland \\ Pori School of Technology and Economics, Tampere University of Technology, Po.Box 300, \\ 28101 Pori, Finland
}

Keywords: learning environments, mobile communication, future visions, elementary education

\begin{abstract}
Mobile and wireless communication technologies are developing rapidly. These technologies could be used to support a pedagogical meaningful, placeand-time independent learning process. At the Pori School of Technology and Economics, Finland, we have started a research and development project in wireless communication's capabilities in primary and early childhood education. In this paper we present a scenario for a problem-based learning in the wireless environment. The mobile devices may become a major communication devices within all kinds of electronic communication and they might displace traditional computer networks in some areas of learning. These technologies have to evaluate today in order to implement the next generation mobile eLearning.
\end{abstract}

\section{INTRODUCTION}

One of the most rapidly developing areas in the field of technology is wireless communication (WCT) and especially mobile phone communication (MCT) (Räihä et al. 1999). The technological breakthroughs in this area, as well as in information technology (IT), will give totally new 
alternatives for school education, including primary and early childhood education. According to the National Strategy of the Finnish Ministry of Education (1995), it is the school's task to give for every boy and girl the necessary skills of information retrieval and knowledge acquisition needed in information. Thus, it is important to find out how the children use WCT/MCT and how they experience it (Laurel 1995, Downes 1995, Downes 1999).

In Finland the children and young people have grown up into a culture of mobile communication; $70 \%$ out of the students in lower secondary schools, $90 \%$ of those in upper secondary schools and $95 \%$ out of the university level students owns a mobile phone. Approximately the same number of the students at the different levels of education use their mobile phones daily both for taking care of their 'businesses' and for other communication with their friends (Ketamo and Multisilta 2001). With modern mobile communication technologies it is possible to support the studying and learning process. For instance, current technology makes it possible to browse the examination calendar, to enter to an examination and to get the examination results by way of a simple WAP-based mobile phone. It's also possible to construct a simple WAP-based learning game (Keiho, Lahti and Multisilta 2000). In addition to learning questionnaires basing on traditional pen and paper-method, also WAP-based learning questionnaires can be utilised. In order to implement a www-like open learning environment utilising mobile technology, radical improvements in performance are needed. Especially, the screen size, cpu-power and data transfer capacity set limitations for the use of current mobile devices as a technique of learning environments. The mobile learning environment may be based on the same general principles as the www-based learning environments. The carefully developed mobile learning environment can make the place-and-timeindependent studying possible on contrary with the www-learning environments which are bound to physical network connections and to workstations located in certain classrooms.

\section{THE WIRELESS COMMUNICATION IN LEARNING-PROJECT}

At the Pori School of Technology and Economics and the Department of Teacher Education in Rauma, Finland, we have started a research and development project in wireless communication's capabilities in primary and early childhood education. The project is multi-scientific and in it WCT is studied from two points of view: 1) WCT as a subject in education, 2) WCT as a means of education. The starting points of the study are the following. 
Wirelessness. No one can still exactly foresee the technological solutions of the mobile learning environments of the future. Like www-techniques, also WAP-techniques serve frames for the environments. However, the WAP-techniques are still quite undeveloped and they cannot yet be utilised as the techniques of a learning environment. Also, the costs of data transfer are still quite high. The disadvantages of wireless PC-techniques include the quite limited operational range and the fairly large size of the mobile computers. However, the costs of data transfer are minor and the performances of the devices can be adjusted to sufficient level for the requirements of a learning environment.

Teaching/instruction. A starting point for instruction is the use of wireless communication in situations where some additional value is to be achieved from it to the teaching. The technology is not used just for itself (technological imperative), but it is tried to be used to support problembased and/or co-operative learning (Hakkarainen, Lonka and Lipponen 1999).

Communication is restricted to interpersonal communication; the manmachine communication is excluded in the context of learning. Thus, technology is regarded only as a tool with which a mobile learning environment applying to and effectively maintaining social knowledge construction (Bereiter and Scardamalia 1993) is made possible.

\section{REQUIREMENTS OF A GOOD LEARNING ENVIRONMENT}

On the basis of learning theories, the following properties are required from a good computer based learning environment: 1) The environment has to support the constructivist point of view on learning and thus it has to counsel the learner to active working. 2) The environment has to support social interaction in order to maintain co-operative or problem-based learning tasks. 3) Delivering information, tasks and objectives should be possible in the environment. 4) Arranging tests and examinations should be possible in the same environment. 5) The environment should support giving feedback. 6) There should be the possibility to extend the environment and openness of the environment. It should be able to bring other teaching materials, documents and tasks to the environment (Ruokamo and Pohjolainen 1998, McGee and Howard 1998, Hopper 1998, Multisilta 1999).

In designing a learning environment especially the users' needs should be taken into account which often differ from the views of the programmer (Häkkinen 1996). A good user-interface is based on the users' images of the functions, and performs whole tasks at a time, and the user does not need to 
be trained to use of the tool first. Also, the instructions for the users have to be planned and accomplished carefully as unclear instructions lead attention away from the essentials.

The purpose of the learning environment in this paper is to emphasise Vygotsky's idea about children learning from each other. A portable mobile learning environment makes possible many different forms of communication with which the children can discuss learning problems or tasks even without seeing each other. The communication may be delivered for instance as traditional phone calls, image calls, literal text-messages, online chat boards or off-line message boards. All these forms can be carried out between two or more partners. It is also possible to arrange for each learner a personal working area where the others can send messages and the learner can respond to them in a way they prefer. In this way, it is possible to arrange the learner a chance for asking for advice from a teacher without the other participants even knowing it. This kind of 'facelessness' has been reported to have enhanced university students' argumentation (Marttunen 1997). The traditional teacher-centred instruction is also possible in the mobile learning environment of this study, but it is assumed that the learning will be self-directed to social inter-student knowledge construction.

\section{SCENARIO - A $5^{\text {TH }}$ GRADE BIOLOGY EXERCISE}

Problem-based learning is very suitable method to elementary school science lessons. Often, when complex exercises are done outside the classroom, teachers work becomes quite hard; the teacher must instruct and control every pupil. When pupils are around the schoolyard, it becomes almost impossible. Also, when doing out-of-class exercises, the need of instructions arises heavily. It is also common, that completed exercises don't reach the aims of the planned exercise because of the lack of the instruction.

This scenario focuses on $5^{\text {th }}$ grade biology exercise, where pupils have to observe how different trees grow. According to their observations, they should draw illustrations on different growing styles and write short explanations to the illustrations. An exercise begins with short introduction in classroom. Each pupil and the teacher get their mobile-pc and after that children spread around the schoolyard.

The wireless network reach pupils, when they are in schoolyard (circleplots in Figure 1). If there is a connection between the server and the workstation, the teacher knows that pupil (or at least the machine) is in the schoolyard. Pupils can individually walk around the schoolyard and same time stay socially connected as in the classroom. In fact, there are even more 
versatile possibilities to communicate to each other than in normal classroom. When doing the exercise, pupil 1 faces difficulties. Normally, she must search the teacher, but in this case she just sends some kind of message to the teacher and the teacher answers in one way or another. In case the instructions were poor, the teacher can give information to all pupils or just answer individually.

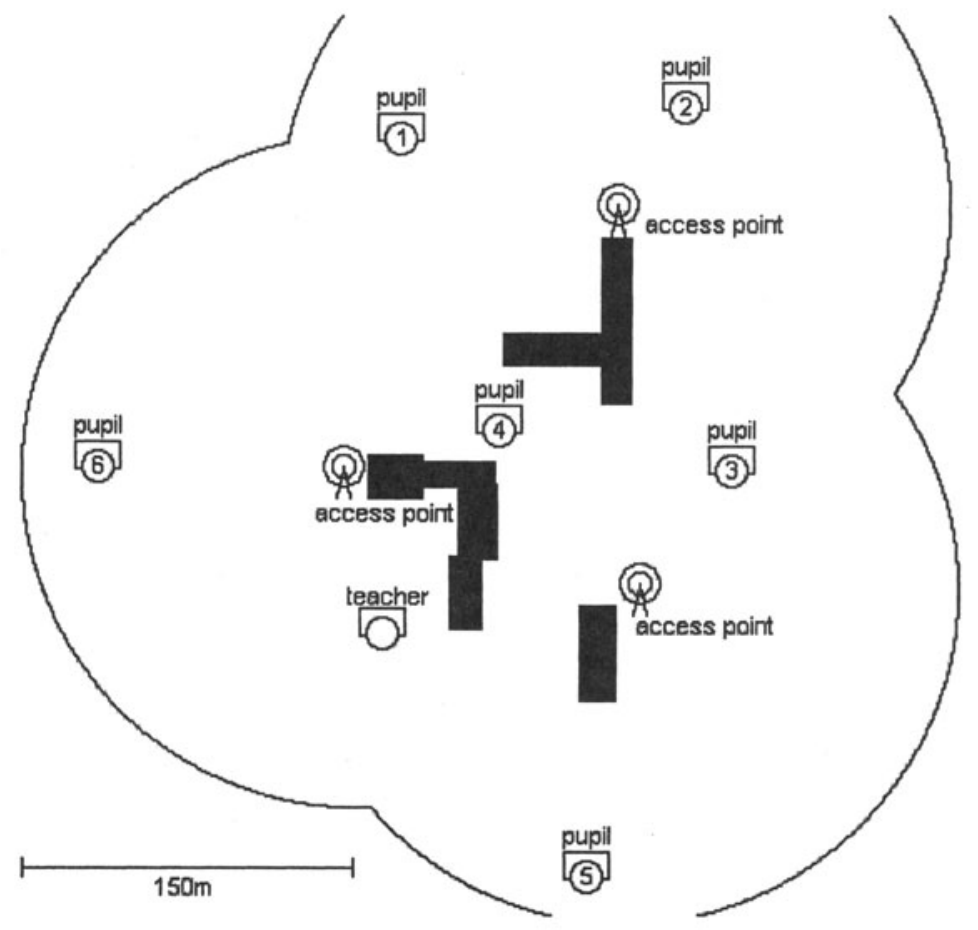

Figure 1. WLAN and pupils in the schoolyard.

A more common case, when pupil 2 want to ask advice from another pupil she can send some individual question and nobody else need to know that. If pupil 2 wants to ask a common question, she can do that also by sending message or by using videoconference to all. When time is up, the teacher can inform everyone by any kind of messages, or even by closing the pupil's workspace.

In this scenario the wireless network is build by using WLAN technology. WLAN is based on access points, which transports the signal between the laptops. There must also be a WLAN pc-card in the laptop. If the WLAN is planned to be just an intranet, the server can be one of the 
laptops. If connection to the internet is needed, server or access point must have a cable connection to the internet. Nowadays a maximum WLAN range between access point and workstation is approximately 300 meters in the open air; in this scenario the range is thought to be smaller because of different blocks in the schoolyard. The total area of scenarios WLAN is reached by using several access points, which reach each other.

In the future, when fast mobile solutions (GPRS/UMTS) are in use, building this kind of network becomes redundant. With those solutions the access points are not needed and specific servers can be replaced by one server, which handles all communication. Also, there would be no limitations in network range. With GPS tracing-systems in future mobile networks, teacher could control the position of pupil quite correctly without seeing the pupil.

In this scenario, learning is seen as a result of social interaction. Technology is seen as a tool for making more versatile communication possibilities and different learning opportunities for different learners. When learning opportunities becomes more versatile, there is more space for different learning styles, and that way the technology might be a good motivation element for learners. Technology is also seen as teacher's assistant, which allows teacher to focus on guiding pupils instead of routine work, like controlling pupils.

\section{DISCUSSION}

Communication technology is rapidly developing and some day the new products with new powerful preferences will be in common use. It is quite possible that internet services (www, email, news etc.) will become available to mobile devices in a few years, and for taking a full advantage from the new solutions, we should study the possibilities of those applications beforehand. In these studies we should focus on the content of the use, not to the usage of the technology. When there is a need to learn the usage of the technology, pupils will manage it easily. On the other hand, using (and learning to use) the mobile devices, pupils and students prefer to ask help from their friends than using any other sources (Ketamo and Multisilta 2001). Accordingly, the teaching of the usage of device could be quite unnecessary, in fact the device should be implemented so that anyone can easily recognise its usage.

The new mobile technology might displace traditional computer networks in some areas of learning support. Mobile devices might, for example, become a major communication devices within all kinds of electronic communication. The role of the computer might become exactly a 
workstation in the meaning of work, not meaning the overall-environment. After all the pc-technology is not disappearing, because of its power in certain areas of learning, but its supremacy in the field of learning environments is certainly over.

\section{REFERENCES}

Bereiter, C. and Scardamalia, M. (1993) Surpassing ourselves. An inquiry into the nature and implications of expertice. Chigago, IL, Open Court.

Downes T. (1995) Children and Electronic Media: The Home-school Connection. In World Conference on Computers in Education VI. WCCE' 95 Liberating the Learner, J. David Tinsley and Tom J. Van Weert (eds.), Chapman \& Hall, London, pp. 543-552.

Downes T. (1999) Playing with Computing Technologies in the Home. Education and Information Technologies, Vol 4, No 1, pp. 65-79.

Finnish Ministry of Education (1995) Koulutuksen ja tutkimuksen tietostrategia. Helsinki, Opetusministeriö, [Information strategy in education and research. Helsinki, Finnish Ministry of Education].

Hakkarainen, K., Lonka, K. and Lipponen, L. (1999) Tutkiva oppiminen: Älykkään toiminnan rajat ja niiden ylittäminen. Wsoy, Porvoo, [Explorative learning: The limits of intelligent activity and surpassing them].

Hopper, M. (1998) Assessment in www-based learning systems: Opportunities and challenges. Journal of Universal Computer Science, Vol 4. [http://www.iicm.edu/jucs_4_4 /assasment_in_www_based/paper.html].

Häkkinen, P. (1996) Design, Take into Use and Effects of Computer-Based Learning Environments - Designer's, Teacher's and Student's Interpretation. University of Joensuu. Publications in Education, No 34.

Keiho, H., Lahti, J. and Multisilta, J. (2000) Teaching WAP Technology as a Part of Multimedia Course. In Proceedings of IFIP World Computer Congress, (eds.), Beijing, China, pp. - .

Ketamo H. and Multisilta, J. (in press) Lapset, Nuoret ja matkaviestintä. [Child, youth and mobile communication] Publications of Pori School of Technology and Economics 34/2001, Pori, Finland.

Laurel B. (1995) The Nature of Computing. Educom Review, Vol 30, Issue 4. pp. 36-42.

Marttunen, M. (1997) Electronical mail as a pedagogical delivery system: An analysis of the learning of argumentation. Research in Higher Education, Vol 38, No 3, pp. 345-363.

McGee, S. and Howard, B. (1998) Evaluating educational multimedia in the context of use. Journal of Universal Computer Science, vol 4, [http://www.iicm.edu/jucs_4_3/evaluating_educational_multimedia_in /paper.html].

Multisilta, J. (1999) Open learning environments - Old wine in new wineskins? In Proceedings of AI-ED, What do we know of open learning environments?, J. Multisilta (ed.), LeMans, France.

Najjar, L. J. (1995) A review of the fundamental effects of multimedia information presentation on learning, [http://www.cc.gatech.edu/gvu/reports/TechReports95.html].

Ruokamo, H. and Pohjolainen, S. (1998) Pedagogical principles for evaluation of hypermedia-based learning environments in matematics. Journal of Universal Computer Science, vol 4.

[http://www.iicm.edu/jucs_4_3/pedagogical_principles_for_evaluation/paper.html]. 
Räihä, K-J., Jääskeläinen, K. and Oesch, K. (1999) Uusi käyttäjäkeskeinen tietotekniikka. Digitaalisen median raportti 5/99, Esiselvitysraportti. Helsinki, TEKES. [New usercentered information technology. Report of digital media 5/99].

\section{BIOGRAPHY}

Harri Ketamo is a researcher at the Pori School of Technology and Economics, Tampere University of Technology, Finland. He has focused on digital learning environments in elementary and higher education and mobile communications among children and youth.

Jarkko Alajääski is a senior lecturer of mathematics at the University of Turku, Department of Teacher Education in Rauma. He has over 50 publications about science education.

Jari Multisilta is the Professor of multimedia at the Pori School of Technology and Economics, Tampere University of Technology, Finland. Prof. Multisilta has published over 50 articles in international conferences and journals. His research interests include applications of multimedia, distance learning and mobile internet technologies. 